\title{
樹木状植生を持つ河床上における 浮遊砂濃度の形成機構
}

\author{
HYDRODYNAMIC MECHANISM OF SUSUPENDED LOAD \\ ON RIVERBEDS VEGETATED BY WOODY PLANTS
}

\author{
湯城豊勝 $^{1} \cdot$ 岡部健士 ${ }^{2}$ \\ Toyokatsu YUUKI and Takeshi OKABE \\ ${ }^{1}$ 正会員 工修 阿南高専助教授 建設システム工学科（テ774-0017 徳島県阿南市見能林町青木 265） \\ 2 正会員 工博 徳島大学教授 工学部建設工学科（テ770-8506 徳島市南常三島町 2-1）
}

\begin{abstract}
Hydrodynamic mechanism of suspended load in open channel flows over woody plants was investigated based on the results of laboratory experiments. In the experiments, three-dimensional distributions of equilibrium sediment concentration were minutely measured in uniform flows over tree models uniformly arranged in a staggered manner. It was clarified that so-called dispersive flux plays an important role in the mass-conservation relationship of suspended load, and also that the diffusion coefficient of suspended sediment is almost proportional to the kinematic viscosity of flow. The experimental results of vertical profiles of horizontally averaged sediment concentration were accurately reproduced by a numerical model that includes an empirical model for the dispersive flux and a $\mathrm{k}-\varepsilon$ turbulent flow model for the diffusion coefficient.
\end{abstract}

Key Words : woody plant, suspended load, mass-conservation relationship, dispersive flux, numerical modeling

\section{1. はじめに}

近年，河道内の植生繁茂領域の拡大とと屯に，樹木の 成長も顕者になり，樹木の管理・保全が重要な課題にな っている. このため, 植生水理に関する研究成果力数多 く報告され，植生を伴う河床上の流れ之流仯現象の解明 か試みられてきた. まず流れに関する研究としては，混 合距離理論に基づくもの ${ }^{1)}$, 渦動粘性係数を用いて流速 分布の摂動解を求めるもの ${ }^{21}$, 高次の乱流クロージャー

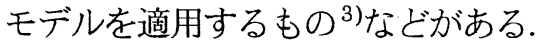

一方, 流砂については，掃流仯を対象として有效掃流 力の低減を, 経験的に求めたもの $)^{4)}$ 抵抗分離法を適用

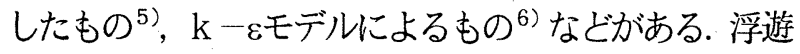
砂については，清水ら ${ }^{7)}$ はLESに基づく平面 2 次元数值 計算から流れ場の非定常構造を抽出し, それか澍林帯の 浮遊孙輸送に及ぼす影響を把握している. 池田ら ${ }^{8)}$ は高 水敷と低水路の境界部に樹林帯を有する水路での実験之,
SDS-2DH モデルに浮遊砂の輸送方程式を組み込んだ数值 計算を行い, 浮遊砂の輸送機構について考察している.

このような研究の流れの中で，筆者ら $\left.{ }^{6)}, 9\right)$ は, より 現実に近い灌木状および樹木状の木本類を模擬した植生 モデルを用いた水理実験を行い，同時に数值計算による

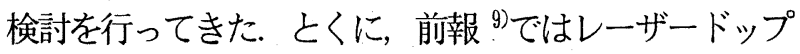
ラー流速計による乱流計測を実施し, 流れの乱流構造の 把握を試みた 流れの数值解法については従来無視され てきた dispersive flux を考慮することの効果を検討 した.

本研究では，今までに明らかにされていなかった浮遊 砂濃度の形成機構を, 詳細な実験デー夕に基づいて考察 した. 水理実験においてはサイフォン式と濁度計による 浮遊秒濃度の計測を行い, その結果と前報の乱流構造に 関する成果を合わせながら濃度の dispersive flux に 注目し, 植生を持つ河床上における浮遊砂濃度の形成機 構を分析した. 


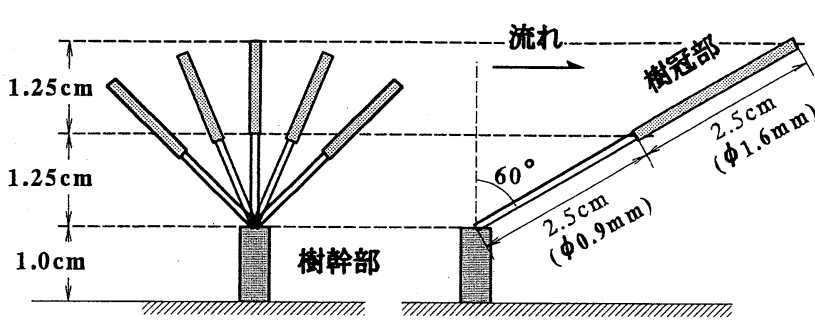

(a) 正面図

表一 1 水理条件

\begin{tabular}{|c|c|c|c|c|c|}
\hline ケース & $\begin{array}{c}\text { 流 量 } \\
\mathrm{Q} \\
(1 / \mathrm{s})\end{array}$ & $\begin{array}{c}\text { 勾配 } \\
\mathrm{i}\end{array}$ & $\begin{array}{c}\text { 水深 } \\
\mathrm{h} \\
(\mathrm{cm})\end{array}$ & $\begin{array}{c}\text { 平均流 } \\
\text { 速 } \mathrm{V}_{\mathrm{m}} \\
(\mathrm{cm} / \mathrm{s})\end{array}$ & $\begin{array}{l}\text { 摩擦速 } \\
\text { 度 u* } \\
(\mathrm{cm} / \mathrm{s})\end{array}$ \\
\hline 1 & 5.45 & $1 / 1000$ & 6.0 & 22.7 & 2.13 \\
\hline 2 & 6.75 & $1 / 667$ & 6.0 & 28.1 & 2.60 \\
\hline 3 & 7.65 & $1 / 500$ & 6.0 & 31.9 & 3.01 \\
\hline
\end{tabular}

図ー1 実験で用いた植生モデルの単体

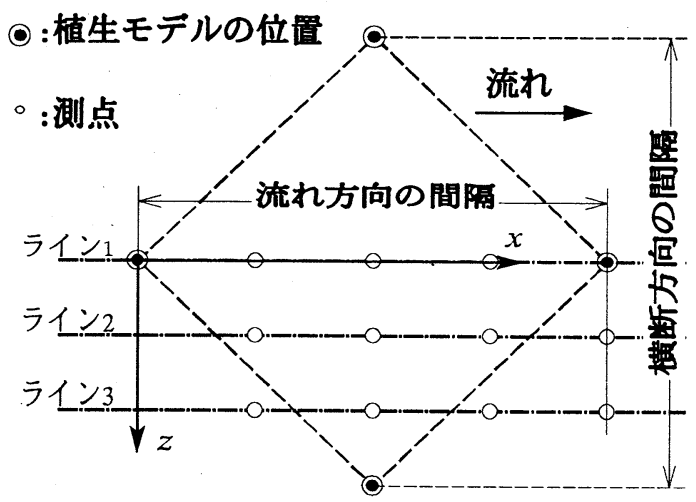

図ー2 配列メッシュ内の測線と測点位置

\section{2. 水理実験}

実験には, 長さ $12 \mathrm{~m}$, 幅 $0.4 \mathrm{~m}$ の水路を使用した. 図 - 1 に実験で使用した樹木状植生モデルの概要を示す. この植生モデルは, 直立した樹幹部と流れによって撓ん だ枝の樹冠部を持つ樹木を想定し，アルミ管に 5 本の銅 線を差し込み，その先端にゴムチューブをかぶせたもの である. 実験では，このような植生モデルを水路床の $7.2 \mathrm{~m}$ の区間に一様な密度て配列した。配列パ夕ーンは, 図一 2 に示すような縦・横断方向間隔が $12 \mathrm{~cm} \times 12 \mathrm{~cm}$ の 千鳥状とした。

実験を行う浮遊砂流で, 定常濃度をつくる方法は以下 の通りである. まず清水流を循環させて, 水路下流端付 近において適当な量の実験砂を供給し，それらが水之同 時に循環する状況で，河床上にわずかの土砂堆積か認め られるまで投入した。濃度は, 配列メッシュ内の単位領 域で空間平均された鉛直分布と，いろいろな高さにおけ る平面分布か赇められた. 前者の計測は採水方式，すな わち自作の 3 連式サイフォン（内径 $2 \mathrm{~mm}$ ）を使用した. 図- 2 に示す 3 本のライン上を, 5 分間に流れ方向の間 隔長さを均等な速度で水平移動して, 約 4.6 リットル採 水した．ここでは詳しい説明を省略するが，この方法は 単位領域から採水することと同等であると考えた。方, 単位領域内における濃度の平面分布の計測は，図一2の ○点において濁度計(KENEK製)を利用して行った。 濁度から濃度への較正は先に述へた採水によるデー夕か ら行った.

実験条件を表一 1 に示す.ここでは水深 $h$ を $6.00 \mathrm{~cm}$ に固定し, 流量 $Q$ と水路床勾配 $i$ を変化させている.

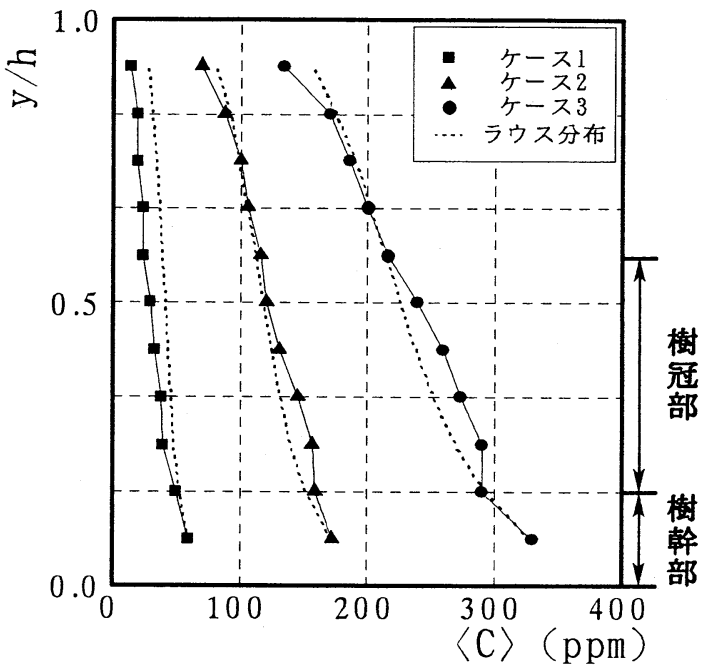

図一 3 平面的に平均された濃度分布

平均流速 $V_{m}$ は連続の式より求められ, みかけの摩擦速 度 $u_{*}$ は $\sqrt{g h i}$ より求められた. 実験に用いた粒子は比重 1.42，粒径 $0.1 \mathrm{~mm}$ のほぼ一様な塩化ビニル製のものであ る. 沈降速度 $w_{f}$ は, ルベイの式で求めると $0.225 \mathrm{~cm} / \mathrm{s}$ になった。

\section{3．実験結果ならびに考察}

\section{(1)空間平均された濃度の鉛直分布}

平面的に積分平均された濃度 $<C>$ の鉛直分布の計測 結果を図一 3 に示す．ここに，yは水路底からの高さで ある. 参考のためにラウス分布曲線を破線で併記してい る. 計測值はラウス分布特有の逆 S字状の様相を呈する ものの, 樹冠部においてはふくらむようになり, 高い濃 度になっている. これは, 底面付近の高濃度の浮遊砂が 通常の乱流より多く上方へ輸送されたと考えられ，この 原因は，樹冠部付近に発生する組織的渦構造によるもの と思われる. ケース 3 とほぼ同条件で行われた前報の横 断流況結果を図-4に再掲すると, 樹冠部に丁度組織的 渦構造か存在しており,この渦が浮遊杪の駆動力になっ ていると思われるが，以下詳細に濃度分布の形成機構を 検討する.

(2)濃度の dispersive flux

ある高さにおける浮遊杪輸送の収支式を,メッシュの 

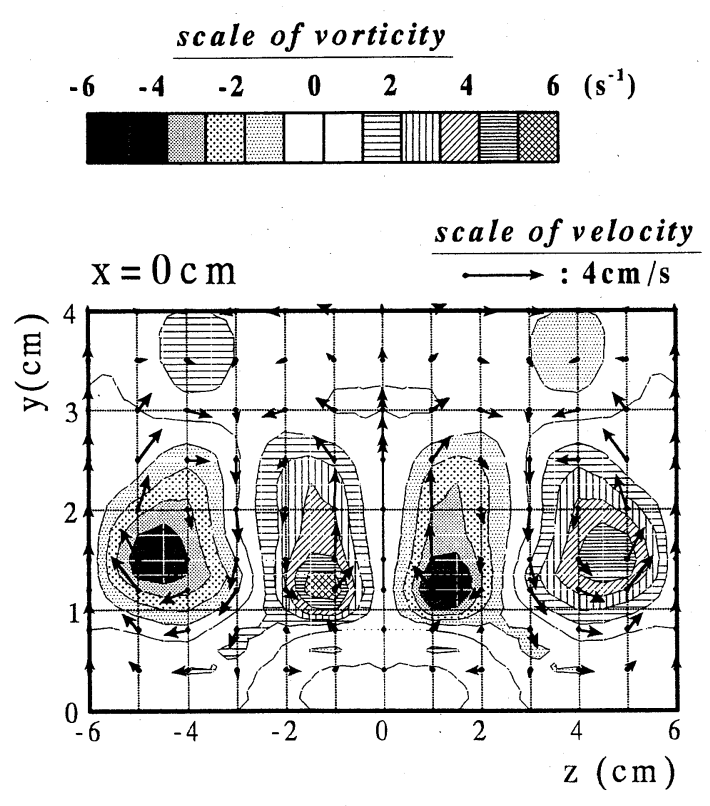

図-4 組織的渦構造

単位領域について積分平均すると次式を得る.

$$
-\varepsilon_{t} \frac{d\langle C\rangle}{d y}+\left\langle C^{\prime \prime} V^{\prime \prime}\right\rangle=w_{f}\langle C\rangle
$$

ここに, $\varepsilon_{t}$ :拡散係数 $\left(\mathrm{cm}^{2} / \mathrm{s}\right), C^{\prime \prime}$ :空間的平均濃度からの 偏差, $V^{\prime \prime}$ :鉛直方向流速の空間的平均值からの偏 差, $<C^{\prime \prime} V^{\prime \prime}>$ : 濃度の dispersive flux である. 流れにおけ る運動量の空間平均值は, 運動量の dispersive flux とよ ばれたので，本論文ではこれに倣って濃度の dispersive flux とよぶ.

式(1)の第 1 項は, 浮遊秒の乱れによる「拡散項」, 第 2 項は組織的渦構造力洔つ鉛直方向への浮遊砂の輸送量 を表す「disipersive flux 項」, 右辺は下方への輸送量を 表す「重力項」である. 拡散項については, 本来は左辺 第 1 項全体が空間的平均值を表すく>に含まれるべきで あるが，そのように扱うと問題か難しくなるため，実用 上の観点から式(1)のようにしている. 左辺第 2 項は, 通 常の開水路流においては 0 であるが，植生中においては V" が大きいので残留すると考えられている.

ところで，前報においては今回のケース 3 とほぼ同条 件の実験による実測値 $V^{\prime \prime}$ が求められている. ここに, 式(1)における上記 3 項の重要度を調べるために, ケース 3を例にとって大きさの項別比較をして図－5に示す. なお，拡散項は重力項から dispersive flux 項を引いた残 差である.

底面付近では dispersive flux 項と拡散項がほぼ等しく なり, 樹幹頂部において dispersive flux 項が極端に大き

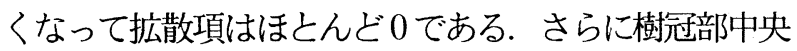
で再び兩者は等しくなって交差しているが, 植生頂部よ りやや下方で dispersive flux 項はほとんど0となり, 重 力項之拡散項か俆り合っている。このように各項の大小 関係は複雑に入れ替わっている。

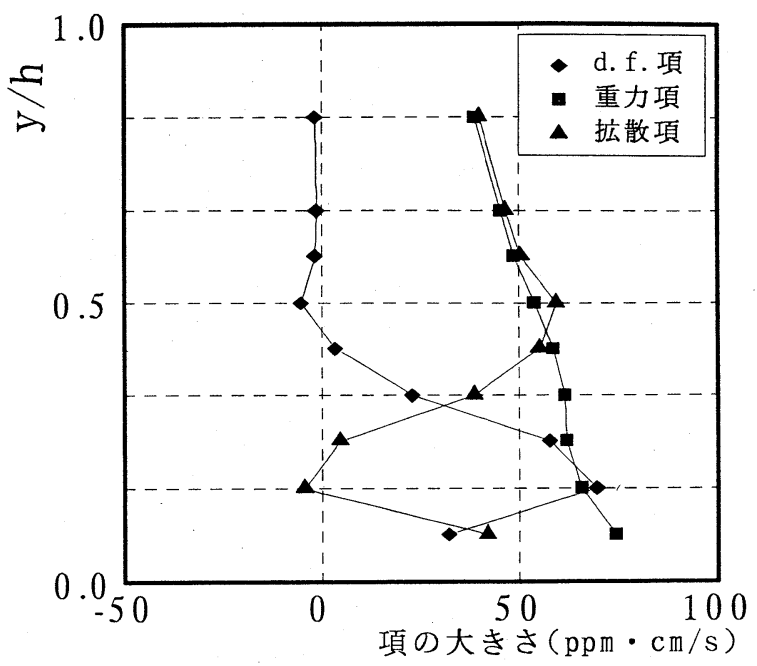

図一5 式(1)における各項の大きさ

濃度分布の予測においては，式(1)から分かるように dispersive flux と拡散係数 $\varepsilon_{t}$ を知る必要があるが, 現段 階ではこれらを求めることができない，そのため，今後 これらの評価法やモデル化が問題になってくる.

さて, dispersive flux のモデル化には何らかの見識が 必要とされるが，そのためには dispersive flux の形成機 構を知らねばならない，ここでは, dispersive flux を構 成する $C^{\prime \prime}$ と $V^{\prime \prime}$ を調べることによって $<C^{\prime \prime} V^{\prime \prime}>$ の概要 が理解できると考え， $C^{\prime \prime}$ とV" の個々の分布特性，なら びに dispersive flux の基になる $C^{\prime \prime} V^{\prime \prime}$ の分布特性をコン タ一図で示した，その結果を図ー6に示す．水の流れは 紙面の上方から下方に流れている.

まず $C^{\prime \prime}$ に注目する. 濃度の平面内変化は水路底で大 きく, 水面では小さくなっている. 水深の半分以下にお いて, 濃度は縦断的に変化しないものの, 横断的には変 化している. 水深の上半分においては, 濃度の縦断的変 化がわずかに見られる. 濃度の横断的変化は水深の下方 と上方では異なり, 水深の下半分では植生モデルを結ぶ 線上で大きく, 植生モデルの中間部では低くなっている. 水深の上方においては， $C^{\prime \prime}$ は植生モデルの線上で低く なり，しかも中間部で高くなって，水深下方のものとは 正負が逆転する領域屯現れる。

つぎにV"に注目する. 濃度と同様に水深の下方では $V^{\prime \prime}$ の縦断的変化がなく, 横断的変化が大きくなってい る.ただし， $C^{\prime \prime}$ は底面近くで大きい值を示すものの, $V^{\prime \prime}$ は $y=1.0 \mathrm{~cm}$ と $1.5 \mathrm{~cm}$ の樹幹部上方で大きくて底面近くで は小さい，とくに，樹幹直上部の値は大きい：この原因 は，底面近くでは水路床により流れか浉制され，樹幹に 沿っては強い上昇流か存在するためと考えられる.この ように樹幹部上方では $V^{n}$ の強い領域か顕著に現れて, 前報でも述へた組織的洞構造か存在する証左になるとと 屯に, 組織的渦構造が水路床に支配されていることが確 認された. 水深の上方においては, 下方と比較してV" の 值は小さくなるものの符号の逆転は見られない．

つぎに，両者の相関をみると明らかに正の相関がみら 


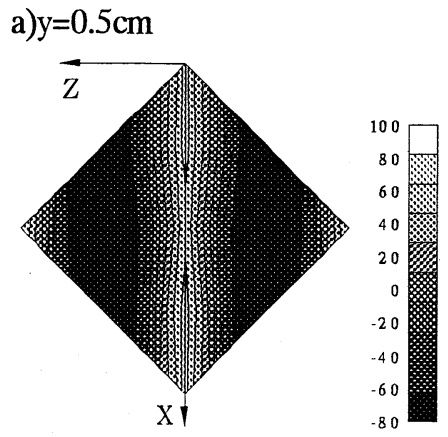

b) $y=1.0 \mathrm{~cm}$

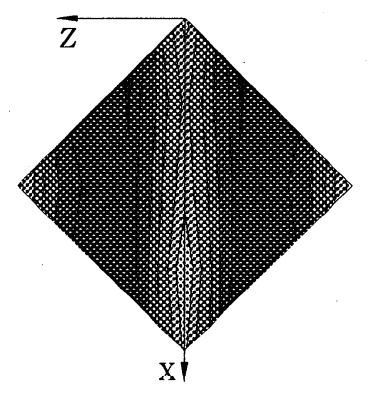

c) $y=1.5 \mathrm{~cm}$

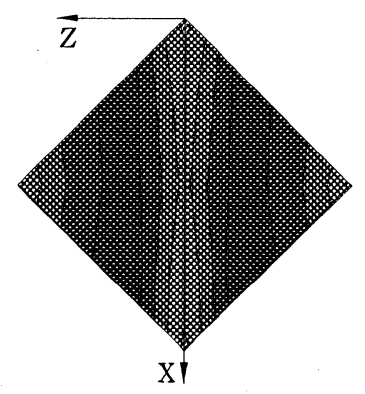

d) $y=3.0 \mathrm{~cm}$

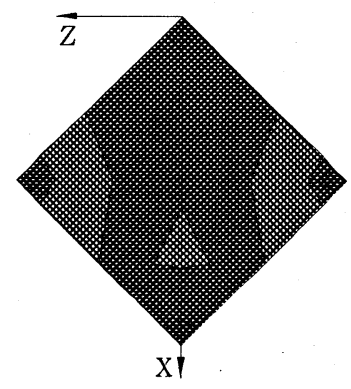

e) $y=5.0 \mathrm{~cm}$

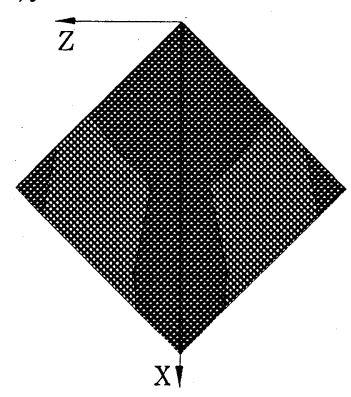

濃度の偏差 $C^{\prime \prime}$
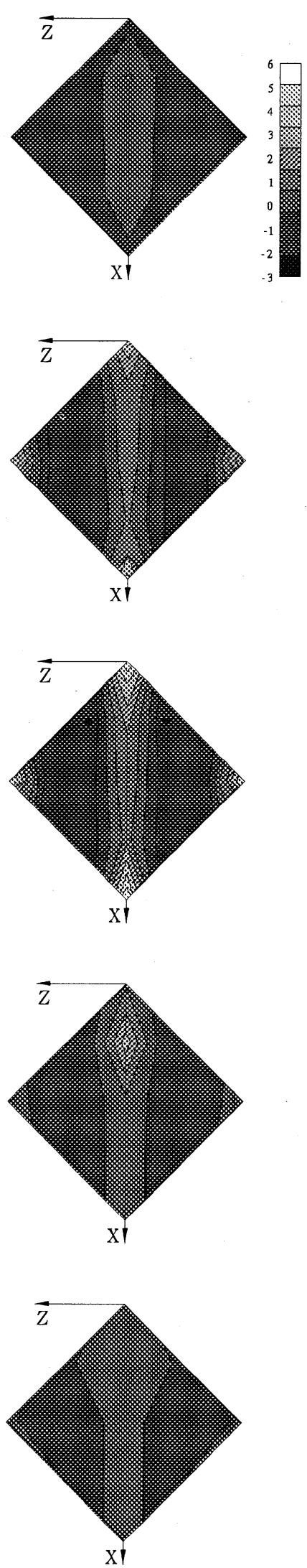

鉛直方向流速の偏差 $V^{\prime \prime}$

図-6 $C^{\prime \prime}, V^{\prime \prime}, C^{\prime \prime} V^{\prime \prime}$ の平面分布
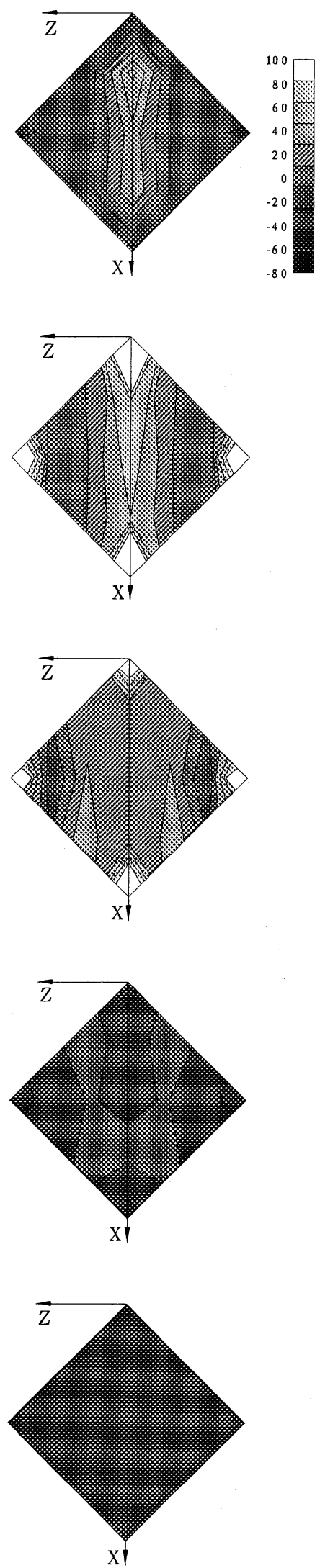

濃度の dispersive flux $C^{\prime \prime} V^{\prime \prime}$ 


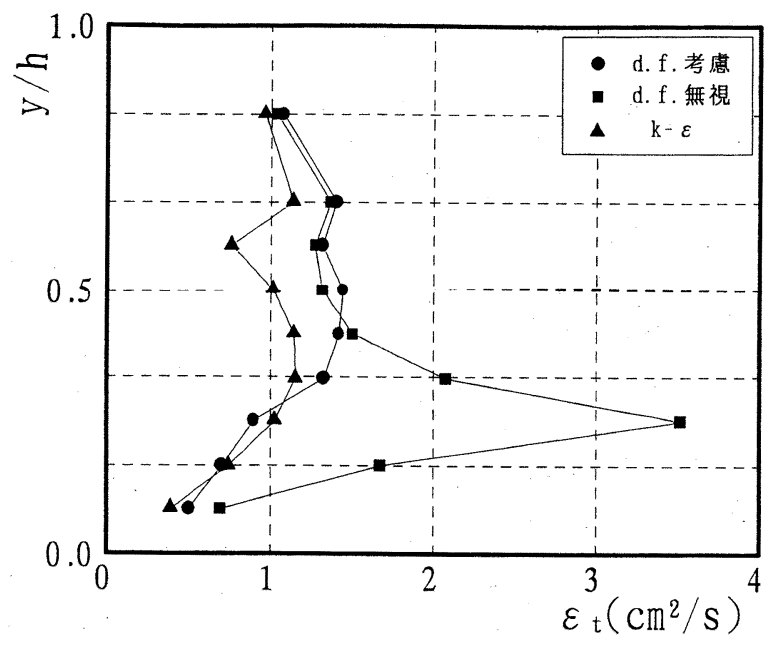

図 -7 拡散係数

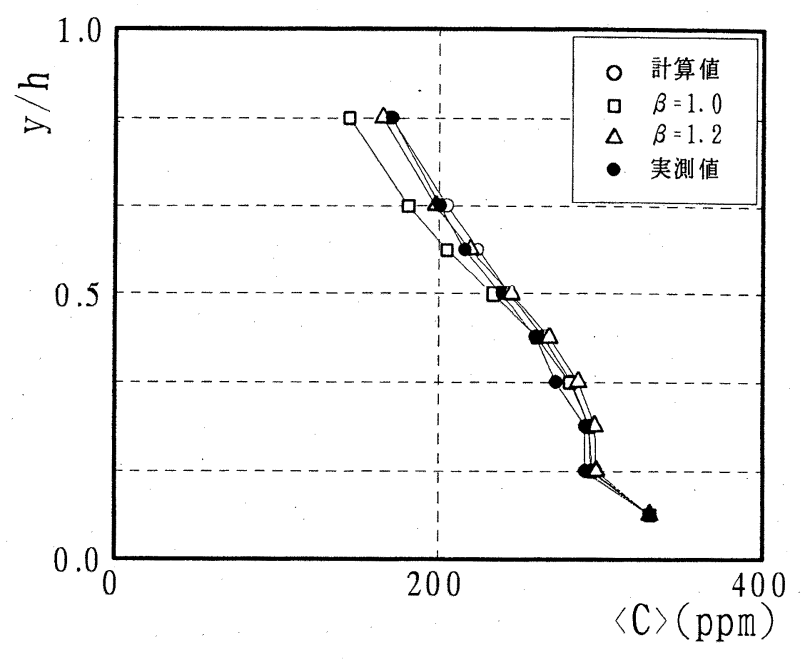

図-8実測値を用いて再現した濃度分布
れる. とくに水深の下半分においては強い相関が示され， 水面に向かう浮遊砂輸送量の多いことか確認される. 水 深の上方においては弱、負の相関が示され輸送量も少な いことを示している.

結合のフラックスとなる $C^{\prime \prime} V^{\prime \prime}$ は，相関関係から予想 されたように，水深の下方で大きい正值，上方で小さい 負值を持っていることか確認される. とくに，樹幹部上 方の $y=1.0 \mathrm{~cm}$ 之 $1.5 \mathrm{~cm}$ における全体の $C^{\prime \prime} V^{\prime \prime}$ 值は大きく, 図一 3 の濃度分布曲線におけるふくらみに影響を及ぼし ていることか確認された，さらに，同水深に姃ける平面 分布の局所的現象として, 樹幹直上部の值がとくに大き 〈なっていることも表されている.このように, $C^{\prime \prime} V^{\prime \prime}$ の 大きさならびに平面分布形状の決定にはV" が大きく寄 与していることがよみとれる.

以上, dispersive flux を規定しているものか組織的渦 構造であり，換言すれば組織的渦構造が dispersive flux の支配因子であることが確認された。

\section{(3)拡散係数}

式(1)から分かるように，浮遊仯の濃度分布を調べるた めには拡散係数 $\varepsilon_{t}$ が必要となる。ここでは，まず dispersive flux を分離する場合としない場合について, 式(1)を逆算した結果について考察した.つぎに, 前報の $\mathrm{k}-\varepsilon$ モデルの計算過程に現れる運動量拡散係数，すな わち渦動粘性係数 $\varepsilon_{m}$ と比較検討した.

その結果を図ー 7 に示す. Dispersive flux 分離した 場合 (d.f.考慮) の $\varepsilon_{t}$ の分布形状は，底面付近加上上方 に向かって徐々に大きくなり, 樹冠部上方で最大值, 植 生頂部で極小值をとり, その後若干大きくなったのち水 面に向かって減少する.

Dispersive flux を分離しないで (dispersive flux=0) 求めたみかけの拡散係数 $\widetilde{\varepsilon}_{t}$ の分布形状は, 底付近から急 激にその值を増し, 樹幹部上方で最大值を示した後, 植生頂部に向かって減少する. さらに植生頂部より上方
では dispersive fluxを分離した場合と同じになる， $\mathrm{k}$ 一 $\varepsilon$ 計算に現れる $\varepsilon_{m}$ は, $\varepsilon_{t}$ と比較して, 樹幹部上方まで はほぼ同じ值になり，その上方ではよく似た分布形状を 示すものの若干小さい值になっている. すなわち, 拡散 係数は, 従来より渦動粘性係数の 1.0 1.3 倍になるとい われ， $\varepsilon_{t}=\beta \varepsilon_{m}$ の関係になっている. この図の上方では $\beta=1.2$, 下方では 1.0 を示しているが全体には 1.2 位にな りそうである.

このように, 精度良い拡散係数を得るためには, 計測 值があれば dispersive fluxをうまく分離することと, 計 算値であれば佩動粘性係数を比例させればよいことが明 らかにされた. ここで，濃度分布を知りたいならば，式 (1)において dispersive fluxを適当にモデル化すればよい ことが分かる.

以上, dispersive flux と拡散係数についてそれぞれの 形成機構の解明を試みた. Dispersive fluxについては組 織的渦構造が大き関与していること, 拡散係数につい ては $\mathrm{k}-\varepsilon$ 計算からの渦動粘性係数と比例関係にあるこ とが明らかにされた。

\section{4. 濃度分布の再現}

実験で得られた濃度分布の再現計算を試みた。まず, dispersive flux の計測值が得られているケース3を計算 した．拡散係数については前項で説明されたように，実 験で得られた値と $\mathrm{k}-\varepsilon$ 計算に現れる值に数種の $\beta$ 値を 与えた. 計算は式(1)の中央差分法で行われ, その結果が 図一8に示されている. 実測値を用いた計算値はかなり 良好な再現結果を得ている. $\mathrm{k}-\varepsilon$ モデルによる拡散係 数については， $\beta=1.0$ と 1.2 の結果を紹介しているが， $\beta=1.0$ では計算值が実測值よりやや小さい傾向を示し, $\beta=1.2$ においてはかなり良好な再現結果を得ている.

ケース1および2については, dispersive flux を計測 していないので何らかのモデル化が必要になる. 現段階 ではどのようなモデルが適切であるか不明であるが，亡 


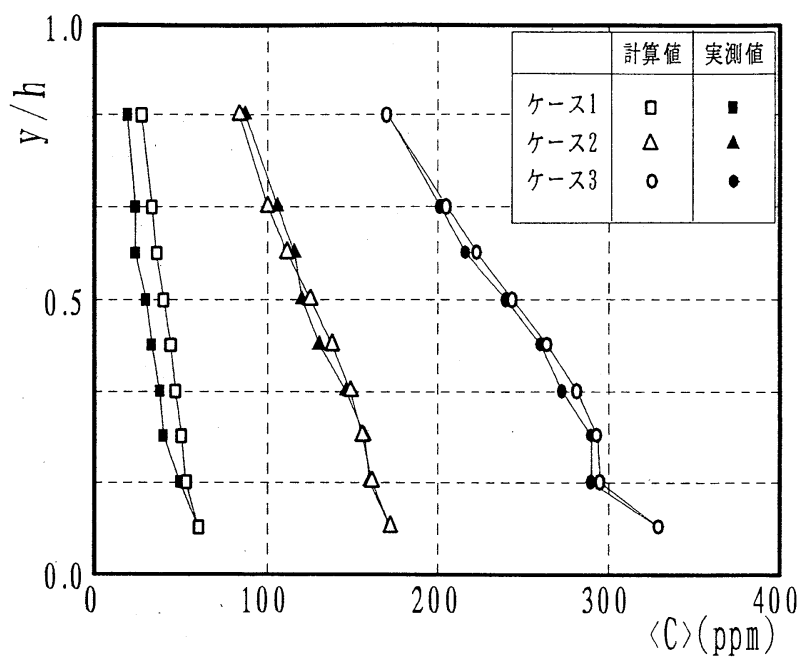

図一 9 dispersive flux のモデル化による濃度の再現

りあえず次元を合わせ， dispersive fluxの分布はいずれ のケースにおいても相似形と考えて次式のように仮定し た.

$$
\left\langle C^{\prime \prime} V^{\prime \prime}\right\rangle=K C_{m} V_{m}
$$

ここに,

$K ：$ 植生モデルの幾何条件によるパラメーターで

$$
K=K_{D} f_{D}\left(\frac{y}{k}\right) \quad \text { とおく. }
$$

$k:$ 植生高さ

$K_{D}$ : dispersive flux の大きさを規定する係数

$f_{D}$ : dispersive fluxの分布形状

$C_{m}:$ 平均濃度

$V_{m}:$ 平均流速

まず，実測值が得られているケース3においてパラメー ターを決めることにした $f_{D}$ は図ー5に示されている dispersive flux 項の分布形状であるが, 直線近似が最 も適しており，下記の分布形状とした.

$$
\begin{array}{rlrl}
f_{D}=\frac{7}{2} \frac{y}{k} & 0 \leq y / k<2 / 7 \\
f_{D}=-\frac{7}{3} \frac{y}{k}+\frac{5}{3} & 2 / 7 & \leq y / k<5 / 7 \\
f_{D}=0 & 5 / 7 \leq y / k
\end{array}
$$

なお， $K_{D}$ の值は 0.0093 という結果が得られた.

これらの結果をケース 1 上2にも適用して, 濃度分布 の再現を試みた結果を図ー9に示す。ケース 3 において は若干計算値が大きいものの全体に良好な結果を得てい る. またケース 2 においても，多少のばらつきがあるも のの良好な結果を示している. ケース1においては，全 体にやや大きめの值を示しているが, 若干左に平行移動 すれば計測值に近づくため, 初期値となる $\mathrm{y}=0.5 \mathrm{~cm}$ 地点 における濃度測定精度の悪さが原因と考えられる. 全体 的にはほほ妥当な值が示され，本モデルにおいても濃度
分布の再現がある程度行えることが分かった，詳しくは 今後の検討課題であり, とくに式(2)の妥当性とパラメー ター $K$ についてはさらに議論を進める必要がある.

\section{5. あとがき}

本研究では, 樹木状の植生帯を通過する流れの中に浮 遊砂办存在する場合を考え, 水理実験を通してその濃度 構造を把握し，とくに濃度に関する dispersive flux や拡散係数について検討し, 最後に濃度の再現計算を試 みた。

実験においては，3連式サイフォンにより空間的に積 分平均された濃度の鉛直分布を浿定し, 濁度計により得 られたデー夕を用いて濃度に関する dispersive flux を求めた. その結果, 濃度の鉛直分布や dispersive flux の平面分布とともに流れの中の濃度構造か明らか にされた. さらに，樹冠部下方においては組織的渦構造 か存在し, dispersive fluxには組織的渦構造が関与し ていることも明らかにされた，拡散係数についても，実 測值や $\mathrm{k}-\varepsilon$ モデルの結果と比較検討されて分布の特性 が明らかにされた. さらに, 実測值による濃度分布の再 現力差分法によって試みられて精度よい結果が得られた。 Dispersive flux のモデル化については今後の検討課 題である.

\section{参考文献}

1)室田明・福原輝幸 : 直立性の植物を有する開水路流れの構 造について，第 28 回水理講演会論文集，pp. 225-231，1984.

2)渡邊康玄・北條紘次・清水康行 : 樹木の存在する河道の流 況特性, 水工学論文集, 第 35 卷, pp. 471-476. 1991.

3)清水義彦 - 辻本哲郎 - 中川博次 : 直立植生層を伴亏流れ場 の数値計算に関する研究，土木学会論文集，No. 447, II-19, pp, 35-44, 1992.

4)平野洋一 - 水原邦夫 -大手桂二 : 植生水路の流水抵抗之掃流 砂量に関する研究, 新秒防, Vol. 40, №. 3(152)pp. 4-10, 1987.

5)石川芳治・藤田英信 - 水原邦夫・成富靖 : 河畔林をもつ河道 における掃流砂量に関する研究。砂防学会誌，Vol. 51, №. 3, pp. 35-43, 1998.

6)井上貴之・岡部健士 ・濱井宣明 - 湯城豊勝 : 樹木状の植生 を伴う河床上の流れ之掃流砂量に関する研究，水工学論文 集, 第 43 巻, pp. 677-682, 1999.

7)清水義彦·辻本哲郎- 小葉竹重機: 平衡植生流れ之浮遊称輸 送に関する数值計算, 水工学論文集, 第 41 巻, pp. 845-850, 1997.

8)池田駿介・河村一弘・福元正武・佐野貴之 : 低水路側岸部に 植生を有する複断面開水路に生じる組織渦と横断方向浮遊少 輸送, 水工学論文集, 第 44 卷, pp. 795-800, 2000.

9)湯城豊勝・岡部健士・濱井宣明 : 樹木状植生を持つ河床上の 流れの乱流構造とその数值解法，水工学論文集，第 45 卷, 847-852, 2001. 